\title{
Effects of Working Capital Management on SME Profitability: Evidence from an Emerging Economy
}

\author{
Luca Sensini $^{1}$ \& Maria Vazquez ${ }^{2}$ \\ ${ }^{1}$ Department of Management and Innovation Systems (DISA/MIS), University of Salerno, Italy \\ ${ }^{2}$ Business Economics Laboratory, UC, Buenos Aires, Argentina \\ Correspondence: Luca Sensini, Department of Management and Innovation Systems (DISA/MIS), University of \\ Salerno, Italy. E-mail: 1sensini@unisa.it
}

Received: February 3, 2020

doi:10.5539/ijbm.v16n4p85

\begin{abstract}
This paper's main objective was to evaluate the influence of working capital management policies on Argentine agro-industrial firms' profitability. To test our hypotheses, we analyzed a sample of 326 companies selected with a stratified random method based on an economic criterion. The data was collected through a structured questionnaire. From a methodological perspective, we used the individual determinants of working capital (DSO, DSI, DPO and CCC) as independent variables, while EBITDA represented the dependent variable. Additionally, we used leverage as a control variable. To assess the impact of individual determinants on corporate profitability, we used the dynamic panel data methodology. This approach has the advantage of controlling the unobservable effects that can influence profitability and endogeneity problems. We also checked the robustness of our results. The results offer several interesting insights. In particular, the results of the variables (DSI, DPO and CCC) showed a negative relationship with firms' profitability, suggesting that investing in inventory and requesting greater extensions from suppliers leads to additional costs that cannot offset the resulting benefits.
\end{abstract}

Keywords: working capital, management, leverage, inventory, emerging market

\section{Introduction}

The financial literature traditionally focused on medium and long-term financial decisions have progressively reevaluated the importance of short-term financial decisions, recognizing that the latter can significantly influence the performance of companies (Smith, 1980; Kim \& Chung, 1990; Shin \& Soenen L., 1998; Khoury et al., 1999; Deloof 2003; Howorth \& Westhead, 2003; Filbeck \& Krueger, 2005; Raheman \& Nasr, 2007; Baños-Caballero et al., 2012; Ukaegbu, 2014; Aktas et al., 2015; among others).

This influence is significant in small and medium-sized enterprises, usually having greater financial constraints and more volatile cash flows than larger companies (Peel et al.,2000; Chen \& Sensini, 2014; Mannetta et al., 2014). SMEs have less negotiating power in dealing with the financial system, generally identified in a single interlocutor, namely the bank.

This circumstance intensely conditions the ability to attract financial resources, very often resulting in indebtedness that is not consistent with investment needs and, at the same time, a strong recourse to short-term debt (Chalmers et al., 2014; Chen et al., 2014; Enow \& Brijlal, 2014).

Furthermore, the lack of managerial skills and adequately qualified human resources can amplify these constraints, leading to a strategic approach that is not consistent with the competitive context's dynamism (Diaz \& Sensini, 2020).

In this perspective, the efficient management of working capital plays a crucial role in favouring business continuity and survival and reducing the risk of financial difficulties (García-Teruel \& Martínez-Solano, 2007; Howorth \& Westhead, 2003; Sensini, 2015; Padachi, 2006; Amendola et al., 2011; Campos et al., 2014).

The recent health emergency and the consequent economic crisis have led to a further credit squeeze that has had and will have a strong impact on SMEs, due to financial constraints and high dependence on bank loans (Sensini, 2020).

This general situation has had and will have a negative influence on SMEs in all world economies. Still, it risks 
having even more severe effects in emerging countries, where economies are more unstable, and the financial system is mainly centred on banks (Das et al., 2000; Campos, 2014; Chalmers et al., 2020).

This situation requires SMEs to pay more attention to the financial dimension and, particularly, to manage working capital.

In the context briefly outlined, this document's main objective is to analyse the influence of working capital management policies on manufacturing companies' profitability in the Argentine agri-food sector. For this purpose, we analysed a sample of 326 companies over seven years (2012-2018) using a dynamic panel data methodology.

This study is interesting for several reasons. First, the management of working capital in agri-food companies is crucial due to the high volatility of raw material prices and significant investments in current assets. Secondly, the Argentine agro-industrial sector is one of the economy's pillars, accounting for about $25 \%$ of the entire manufacturing sector. Thirdly, despite some foreign multinationals' presence, the sector is characterised by a substantial prevalence of SMEs. Furthermore, this study can help entrepreneurs and managers learn more about financial dynamics and implement adequate working capital policies. Finally, this study's results enrich the literature investigating the relationship between working capital and performance, providing further empirical evidence from an emerging economy, such as Argentina.

This paper is organised as follows. The next section examines the relevant literature and develops research hypotheses. Section 3 describes the data and models used, while the next section analyses and comments on the results. Finally, the last section contains the concluding remarks, also highlighting the limitations of the research.

\section{Literature Review and Research Hypotheses}

The working capital management policies concern decisions regarding current assets and current liabilities. The empirical researches that have studied the relationship between WCM and profitability have had a remarkable development in the last twenty years, as evidenced by the substantial literature produced on this topic (Khoury et al., 1999; Arcos \& Benavides, 2006; Falope \& Ajilore, O.T., 2009; Azam \& Haider, 2011; Abuzayed, 2012; Atkas et al., 2015; Prasad et al., 2019; Sensini, 2020; Chalmers et al., 2020; Boisjolya et al., 2020; among others).

Studies that investigated the relationship between working capital management policies and profitability have shown conflicting results, highlighting different views.

Some researchers have suggested that increasing investment in working capital has a positive impact on profitability, as it can lead to increased sales, better customer relationships, reduced supply costs and information asymmetry (Smith, 1987; Emery, 1987; Blinder \& Maccini, 1991; Fazzari \& Petersen, 1993; Wang, 2002; Deloof, 2003; Lazaridis \& Tryfonidis, 2006; García -Teruel \& Martínez-Solano, 2007; Zariyawati et al., 2009; Erasmus, 2010; Aktas et al., 2015).

Other researchers have shown that the increase in working capital has a negative impact on profitability, as it leads to a rise in financial and storage costs (Kim \& Chung, 1990; Ek \& Guerin, 2011; Alipour, 2011; Karaduman et al., 2011) and an increase in financial hardship and the likelihood of bankruptcy (Kieschnick et al., 2013).

Finally, other scholars have suggested an inverse U relationship, arguing that working capital investments produce positive effects until an optimal level is reached. Above this level, further investments produce negative results.

Previous studies have suggested various indicators to measure performance and efficiency in the management of working capital. Specifically, return on assets (ROA), return on equity (ROE), earnings before interest and tax (EBIT), earnings before interest, taxes and amortization (EBITDA), return on invested capital (ROIC), gross operating profit (GOP) or net (NOP) and Tobin's Q ratio were the most used proxies to measure profitability. Simultaneously, the Cash Conversion Cycle (CCC) and the Net Trade Cycle (NTC) were the most used proxies to calculate working capital management efficiency.

The literature has investigated the relationship between WCM and profitability, initially focusing on listed and larger companies and, then, on small and medium-sized enterprises. Most of these studies investigated the above relationship in the context of developed economies (Lazaridis \& Tryfonidis, 2009; Gill et al., 2010). In recent years, several researchers have focused attention on companies in emerging economies, mainly examining companies listed on the Stock Exchange (Mathuva, 2010; Zayanderoody, 2011; Gachira et al., 2014; Marobbe, 2014; Iqbal \& Zhuquan, 2015; among others). However, these companies do not adequately represent the production structure of these countries, made up mainly of a myriad of small and medium-sized enterprises which, with the well-known financial and resource constraints (human, technological, etc.), contribute significantly to economic and social stability (Lee et al., 2012; Chalmers et al., 2020; Ling et al., 2008; Hossain \& Kauranen, 2016; McCann \& Ortega, 2016). 
In emerging economies, the lower political and economic stability, the moderate development and instability of the financial markets, and the climate of uncertainty that characterizes the reference context make investment and financing decisions for companies riskier. Moreover, these choices are often strongly conditioned by the company's sole interlocutor to provide financial resources, the banking system (Alvarez et al., 2021).

In the context briefly outlined, investments in working capital represent a significant part of manufacturing SMEs' assets in the agro-industrial sector.

These companies are susceptible to strong instability and volatility of purchase and sale prices, making working capital management even more complicated. Furthermore, small producers' widespread presence (suppliers of large retailers) often determines longer credit collection times.

Consequently, these investments' management policies significantly impact these companies' profitability, financial balance, and risk level.

This paper uses the variables Accounts receivable (AR), Accounts Payable (AP), Inventories (I), and Cash Conversion Cycle (CCC) to evaluate the impact of each component of working capital on efficiency and profitability. Below, we have developed our research hypotheses for each variable, according to the reference context and the main existing literature on this topic.

\subsection{Accounts Receivable}

The sales policy and the related credit policy are traditionally measured by the collection period or sales outstanding (DSO). The granting of payment extensions can favour an increase in sales and growth in customers, increasing turnover. However, such a policy also results in higher investment in working capital, increasing the risk of customer's non-payment (Alvarez et al., 2020; Raheman \& Nasr, 2007; Diaz \& Vazquez, 2019).

In this regard, the literature suggests a significantly negative relationship between DSO and profitability (Deloof, 2003; García-Teruel \& Martínez-Solano, 2007, Raheman \& Nasr 2007, Karaduman et al., 2010; Lazaridis \& Tryfonidis, 2006).

Therefore, we establish the following first hypothesis:

H1) There is a negative relationship between DSO and profitability.

\subsection{Inventories}

The inventory represents the link between production and sale (Campos et al., 2015; Sensini, 2020) and measures the average number of days from delivering raw materials to the sale of products finished, or days sales inventory (DSI).

The empirical literature on the relationship between inventory management policies and profitability has obtained conflicting and, in some cases, not significant results (Abbasi \& Bosra, 2012).

On the one hand, some authors have suggested that high inventory levels lead to increased costs and risks, thereby reducing business profitability (Shin \& Soenen, 1998; Vishnani \& Shah, 2007; Falope \& Ajilore, 2009; Stephen \& Elvis, 2011; Vahid et al., 2012; Gul et al., 2013).

On the other hand, some authors have suggested that investing in inventory reduces possible interruptions in production and sales, allows to limit the negative effects of price fluctuations and favours obtaining discounts on the purchase of inputs (Mathuva, 2010; Javid \& Dalian, 2014; López-Pérez et al., 2018). In this perspective, high inventory has a positive effect on profitability.

Finally, other authors have suggested increasing inventory produces positive results until an optimal level is reached. However, after exceeding this level, the investment negatively affects profitability, leading to an increase in costs (Chalmers et al., 2014; Diaz \& Vazquez, 2019; Mannetta et al., 2020).

Therefore, taking up the results of the literature, our hypotheses are the following:

H2a) There is a negative relationship between DSI and profitability;

H2b) There is a positive relationship between DSI and profitability;

H2c) There is an inverted U shaped relationship between DSI and profitability.

\subsection{Accounts Payable}

The purchase policy of inputs is traditionally measured by the payment period or days payable outstanding (DPO). The empirical literature that investigated the relationship between DPO and profitability has highlighted conflicting results. 
On the one hand, some authors have suggested a positive relationship between DPO and profitability (Mathuva, 2010; Musau, 2015). In this perspective, obtaining deferred payments can represent a cheaper and more flexible source of financing than bank debt (García-Teruel \& Martínez-Solano, 2007; Kouvelis \& Zhao, 2012). Especially in emerging economies, where the financial system is less developed, the increase in payment terms can also reduce SMEs' financial constraints (Deloof, 2003).

On the other hand, some authors have suggested a negative relationship between DPO and profitability (Raheman \& Nasr, 2007; Vishnani \& Shah, 2007; Vahid et al., 2012; Gul et al., 2013; Javid \& Dalian, 2014). In this perspective, the request for deferred payments can lead to the loss of discounts and the incurring of implicit financial costs that can damage profitability (Deloof, 2003).

Following the literature, our research hypotheses are as follows:

H3a) There is a positive relationship between DPO and profitability;

H3b) There is a negative relationship between DPO and profitability.

\subsection{Cash Conversion Cycle}

The Cash Conversion Cycle (CCC), first proposed by Gitman (1974), expresses the time interval between the outflow of financial resources linked to purchases (DSI, DPO) and the inflow of financial resources related to sales (DSO). The measurement of this indicator summarizes the trend of the single components previously considered, representing a relative proxy capable of expressing the efficiency in the management of working capital (Jose et al. 1996; Gentry et al., 1990).

Empirical research has shown conflicting results regarding the relationship between CCC and profitability.

Some authors have discovered a negative relationship between an increase in this variable and profitability, determined by a greater need for financial resources (Shin \& Soenen, 1998; Nobanee, 2009; Enow \& Brijlal, 2014; Musau, 2015; Mathuva, 2010; Arcos \& Benavides, 2006; Mandujano-Herrera \& Navarro-Orihuela, 2015).

Conversely, other authors suggest that excessively low CCC may limit its ability to increase sales and revenue. Therefore, it may be worthwhile to increase the CCC as long as the benefits deriving from this increase do not exceed the opportunity costs (Deloof, 2003). Consequently, some research shows a positive relationship until an optimal CCC level is reached and, once that threshold is exceeded, a negative relationship. In this perspective, Baños-Caballero et al. (2014) suggest an inverted U-shaped relationship between CCC and profitability.

Therefore, our research hypotheses are as follows:

H4a) There is a negative relationship between CCC and profitability.

H4b) There is an inverted U-shaped relationship between CCC and profitability.

\section{Research Design and Sample}

Our study analyzes Argentine agri-food companies. The companies used to train the population to extract the sample were selected in the Pampas and Buenos Aires province. We have chosen these geographical areas as most of the country's agri-food production is concentrated in these areas. The sampling was carried out in a probabilistic way, using a stratified random approach based on an economic criterion (Amendola et al., 2020). This setting improves the estimates' efficiency and the subsequent analysis's significance. The introduction of the economic discriminant (total assets, turnover, number of employees, etc.) made it possible to select companies adequately representative of the reference population.

We used a two-part structured questionnaire for data collection. The first was aimed at collecting general information regarding the company (Governance, Strategies, Composition of the shareholder structure, Level of Studies, Employees, Production Processes, etc.), while the second was aimed at collecting the financial data necessary to build all the variables of interest in this paper.

The sample size was set at 1000 units to ensure an error $|d| \leqslant 0.055$ and a probability of 0.95 , as shown below:

$$
n=\frac{n_{0}}{1+\frac{n_{0}}{N}}
$$

where $\mathrm{N}$ is the population size and $\mathrm{n} 0$ is given by:

$$
n_{o}=\frac{z^{2}(0.975) p(1-p)}{\varepsilon^{2}}
$$

The maximum level of variability was fixed, assuming a $p=0.5$. 
To encourage the selected companies' participation and increase the response rate, we directly contacted all the sample companies. At the deadline for the closure of the data collection phase, set for 30 June 2020, 326 agri-food companies completed the questionnaire. The response rate was, therefore, $32.6 \%$.

The individual determinants of working capital (DSO, DSI, DPO and CCC) represent the independent variables. Furthermore, we used leverage as a control variable, in line with what the literature suggests (Padachi, 2006; Shin \& Soenen, 1998).

To measure the firm's profitability, which represents the dependent variable, we used EBITDA. This indicator is more reliable and is not influenced by discretionary items, such as depreciation, depreciation and taxes (Parisi et al., 2014).

Table 1 summarizes all the variables used and the computation methods.

Table 1. Variables of interest and computation methods

\begin{tabular}{lll}
\hline & Variables & Computation Methods \\
\hline Dependent & Firm Profitability (P) & EBITDA/Total Assets \\
Independent & Days Sales Outstanding (DSO) & (Accounts Receivable/Sales) *365 \\
& Days Sales Inventory (DSI) & $(1 /$ Stock Turnover) *365 \\
& Days Payable Outstanding (DPO) & Accounts Payable/Cost of Goods \\
Control & Leverage (LEV) & Total Debts/Total Assets \\
\hline
\end{tabular}

To assess the impact of individual determinants on corporate profitability, we used the dynamic panel data methodology. We have chosen this approach as it has the advantage to control the unobservable effects that can influence profitability and endogeneity problems. Furthermore, this model allows to adequately assess the variability of profitability in the agri-food sector (Chaddad \& Mondelli, 2013; Hirsch et al., 2020).

Therefore, we tested the following regression model:

$$
P_{i t}=\beta_{0}+\beta_{1} P_{i t}+\beta_{2} X_{i t}+\beta_{3} X_{i t}^{2}+\beta_{4} L E V_{i t}+\beta_{5} L E V_{i t}^{2}+\alpha_{i t}+\lambda_{t}+\varepsilon_{i t}
$$

where $X_{i t}$ represents the set of independent variables relating to working capital management and $\alpha$ i indicates the unobservable heterogeneity. The $\lambda_{t}$ indicator represents the uncontrollable variable capable of influencing companies' profitability and, finally, $\varepsilon_{i t}$ is the random disturbance.

All explanatory variables of the model are considered endogenous. Furthermore, we have inserted the quadratic relation to test the validity of the hypotheses $\mathrm{H} 2 \mathrm{c}$ ) and $\mathrm{H} 4 \mathrm{~b}$ ) and verify the possible presence of an inflexion point.

\section{Empirical Results and Discussion}

Table 2 shows the main descriptive statistics of the variables used in the analysis.

Table 2. Descriptive statistics ( $\mathrm{N}=326$ firms)

\begin{tabular}{llll}
\hline Variables & Obs & Mean & SD \\
\hline P & 2.282 & 0.08 & 0.37 \\
DSO & 2.282 & 74.52 & 56.21 \\
DSI & 2.282 & 78.23 & 61.18 \\
DPO & 2.282 & 46.81 & 53.25 \\
CCC & 2.282 & 93.11 & 84.27 \\
LEV & 2.282 & 0.54 & 0.35 \\
\hline
\end{tabular}

Within the limits of these data's significance, the results show an average profitability of about $8 \%$. The DSO and DSI are equal to 74 and 78 days, the DPO to 47 and the CCC to 93 days.

We developed our model using the GMM estimator (Arellano \& Bond, 2001), building four different models to evaluate each component's effect on the firm's profitability. Furthermore, for the hypotheses that predict an inverted shaped U relationship, we have developed two models. The first aimed at verifying the linear relationship (A) and the second the quadratic one (B).

Furthermore, we checked for potential errors in the models, using Hansen's J statistics and the AR index (Arellano \& Bond, 1991). 
Table 3. GMM estimations

\begin{tabular}{lllllll}
\hline \multicolumn{5}{c}{ Model A } & \multicolumn{5}{c}{ Model B } \\
\hline P & H1 & H2 & H3 & H4 & H2c & H4b \\
& 0.129 & 0.08 & 0.133 & 0.089 & 0.063 & $(0.093)$ \\
DSO & $(0.14)$ & $(0.12)$ & $(0.13)$ & $(0.13)$ & $(0.12)$ & $(0.12)$ \\
& -0.009 & & & & & \\
DSI & $(0.01)$ & & & & & \\
& & $-0.047^{* *}$ & & & & \\
DSI2 & & $(0.02)$ & & & & \\
& & & & & $-0.067^{\wedge}$ & \\
DPO & & & & & $(0.02)$ & \\
& & & $-0.033^{\wedge}$ & & & \\
CCC & & & $(0.02)$ & & & \\
& & & & $-0.023^{\wedge}$ & & \\
CCC2 & & & & $(0.02)$ & & \\
& & & & & & -0.006 \\
LEV & $-0.069^{\wedge}$ & $-0.087^{*}$ & -0.059 & -0.077 & -0.056 & -0.061 \\
& $(0.02)$ & $(0.03)$ & $(0.06)$ & $(0.04)$ & $(0.05)$ & $(0.05)$ \\
LEV2 & 0.021 & 0.015 & 0.019 & 0.021 & 0.012 & 0.016 \\
& $(0.01)$ & $(0.01)$ & $(0.02)$ & $(0.01)$ & $(0.02)$ & $(0.01)$ \\
F test & 1.14 & $48.39^{* * *}$ & $41.39^{* * *}$ & $1.61^{* *}$ & $1.69^{* *}$ & $43.27^{* * *}$ \\
Hansen J & 124.31 & 103.2 & $134.57^{*}$ & 112.4 & 131.2 & 125.16 \\
AR 1 test & $-2.31^{* *}$ & $-2.25^{* *}$ & $-2.35^{* *}$ & $-2.29^{* *}$ & $-2.39^{* *}$ & $-2.27^{* *}$ \\
AR 2 test & 0.78 & 0.83 & 0.84 & 0.79 & 0.77 & 0.71 \\
\hline
\end{tabular}

Note. ${ }^{* * *}, * *, *$, and ${ }^{\wedge}$ denote a $\mathrm{p}$ value of $.001, .01, .05$, and .1, respectively.

Contrary to what has been highlighted in the literature analysis, the results show that credit policy (DSO) does not influence companies' profitability; therefore, we reject the first two research hypotheses (H1a and H1b).

The inventory management policy shows a negative relationship with profitability, confirming hypothesis $2 \mathrm{a}$. This result suggests that in agro-industrial companies, the containment of storage costs is considered more important than the possible advantages deriving from a potential interruption of production. Furthermore, the high fluctuation in raw materials' purchase prices does not seem to be a determining factor in buying larger quantities in periods characterized by falling prices.

Obtaining greater extensions from suppliers (DPO) presents a negative relationship with its profitability, confirming hypothesis $3 \mathrm{~b}$. Consequently, the deferral of payments to suppliers results in implicit financial charges and the loss of discounts.

Besides, in line with the prevailing literature, the Cash Conversion Cycle shows a negative relationship with its profitability, confirming hypothesis $4 \mathrm{a}$.

Finally, in some of the models developed, leverage is negatively correlated with the firm's profitability.

To evaluate the reliability and robustness of the results, we used fixed effects and random effects estimators. As a preliminary, we carried out the Hausman test (1978). The test results showed that fixed effects estimators were preferable. The results are shown in Table 4. 
Table 4. Robustness check

\begin{tabular}{|c|c|c|c|c|c|c|}
\hline & Model A & & & & Model B & \\
\hline & H1 & $\mathrm{H} 2$ & H3 & $\mathrm{H} 4$ & $\mathrm{H} 2 \mathrm{c}$ & $\mathrm{H} 4 \mathrm{~b}$ \\
\hline \multirow[t]{2}{*}{ DSO } & $-0.018 * *$ & & & & & \\
\hline & $(0.01)$ & & & & & \\
\hline \multirow[t]{2}{*}{ DSI } & & $-0.035^{* *}$ & & & & \\
\hline & & $(0.02)$ & & & & \\
\hline \multirow[t]{2}{*}{ DSI2 } & & & & & $-0.071 * * *$ & \\
\hline & & & & & $(0.02)$ & \\
\hline \multirow[t]{2}{*}{ DPO } & & & $-0.019 * *$ & & & \\
\hline & & & $(0.01)$ & & & \\
\hline \multirow[t]{2}{*}{$\mathrm{CCC}$} & & & & $-0.025 * * *$ & & \\
\hline & & & & $(0.02)$ & & \\
\hline \multirow[t]{2}{*}{$\mathrm{CCC} 2$} & & & & & & $0.005^{*}$ \\
\hline & & & & & & $(0.00)$ \\
\hline \multirow[t]{2}{*}{ LEV } & $-0.042^{\wedge}$ & $-0.047^{*}$ & $-0.045^{*}$ & $-0.044^{\wedge}$ & $-0.043^{*}$ & $-0.061 * *$ \\
\hline & $(0.02)$ & $(0.02)$ & $(0.02)$ & $(0.01)$ & $(0.02)$ & $(0.01)$ \\
\hline \multirow[t]{2}{*}{ LEV2 } & $0.043 * * *$ & $0.041 * * *$ & $0.043 * * *$ & $0.044 * * *$ & $0.043^{* * *}$ & $0.042 * * *$ \\
\hline & $(0.00)$ & $(0.00)$ & $(0.00)$ & $(0.00)$ & $(0.00)$ & $(0.00)$ \\
\hline $\mathrm{R} 2$ & 0.063 & 0.069 & 0.072 & 0.071 & 0.075 & 0.072 \\
\hline
\end{tabular}

Note. ${ }^{* * *}, * *, *$, and ${ }^{\wedge}$ denote a $\mathrm{p}$ value of $.001, .01, .05$, and .1, respectively.

Overall, the results confirm the GMM analysis, showing greater statistical significance. However, the research highlights some elements worthy of further consideration.

In particular, although the values of DSI and CCC confirm the negative relationship with corporate profitability, the estimators seem to highlight a U-shaped relationship between these variables. These results suggest that until an optimal level of inventory and CCC is reached, the relationship is positive and, once this level is exceeded, the same relationship becomes negative. However, the GMM approach is more appropriate for assessing the persistence of profits, endogeneity and any bias. Consequently, we believe that the relationship between each variable used and profitability is mainly linear; however, it can present a U-shaped relationship in the hypotheses outlined above.

\section{Concluding Remarks}

This paper's main objective was to evaluate the influence of working capital management policies on Argentine agro-industrial enterprises' profitability. The sample companies were selected in the Pampa and Buenos Aires provinces, as most of the country's agri-food production is concentrated in these areas. To improve the estimates' efficiency and the subsequent analysis's significance, we performed a stratified random sampling based on an economic criterion. The data was collected through a structured questionnaire.

From a methodological perspective, we used the individual determinants of working capital (DSO, DSI, DPO and CCC) as independent variables, while EBITDA represented the dependent variable. Additionally, we used leverage as a control variable.

We used the dynamic panel data methodology to assess the impact of the individual determinants on corporate profitability. This approach has the advantage of controlling the unobservable effects that can influence profitability and endogeneity problems. We also checked the robustness of our results.

The results offer several interesting insights. In particular, the granting of longer extensions to customers (DSOs) does not affect profitability. Empirical findings, however, must be interpreted according to the type of clientele of the producers. Many producers have little room for manoeuvre in commercial policy, as they are suppliers of large retailers who often impose prices and conditions of sale. Other producers, on the other hand, have a more diversified clientele. In such cases, probably a more aggressive commercial policy could lead, within certain limits, to a different relationship with profitability.

In line with other previous empirical research, the results of the other variables (DSI, DPO and CCC) showed a negative relationship with the profitability of firms, suggesting that investing in inventories and requesting more extensions from suppliers leads to additional costs that they are unable to compensate for the benefits resulting from different management policies. 
This paper is important for several reasons. First, the results can help entrepreneurs and managers of agro-industrial SMEs define and implement their working capital management policies. In the analyzed sector, characterized by high price volatility, strong customer bargaining power and, sometimes, long periods of raw materials storage, controlling the critical variables of working capital and profitability can be fundamental for survival and business development. Furthermore, this paper's results show empirical evidence for an emerging economy, providing other results regarding the relationship between WCM and profitability.

However, this study has limitations that stimulate the development of further research. Firstly, the number of companies that participated in the study consisted of 326 agro-industrial companies. The definition of a larger sample would perhaps have allowed us to obtain more generalizable results. Finally, the results must be interpreted, bearing in mind that agro-industrial companies' production processes can differ from each other. Therefore, the analysis of companies that carry out a specific production could lead to different results than those obtained in this document.

\section{Acknowledgments}

The authors would like to thank all BeLab researchers for their valuable help in processing the questionnaire data.

\section{Authorship contribution Statement}

Sensini L.: Conceptualization, Introduction, Methodology, Data Analysis, Results and Discussion; Concluding Remarks.

Vazquez M.: Data curation, Data Analysis, Results and Discussion, Concluding Remarks.

\section{References}

Abbasi, E., \& Bosra, S. A. (2012). The effect of the cash conversion cycle on profitability in Tehran Stock Exchange. World Research Journal of Financial Economics and Stochastics, 1(1), 1-7.

Abuzayed, B. (2012). Working Capital Management and Firms' Performance in Emerging Markets: The Case of Jordan. International Journal of Managerial Finance, 8(2), 155-179.

Aktas, N., Croci, E., Petmezas, D. (2015). Is working capital management value-enhancing? Evidence from firm performance and investments. Journal of Corporate Finance, 30, 98-113.

Alipour, M. (2011). Working capital management and corporate profitability: Evidence from Iran. World Applied Sciences Journal, 12(7), 1093-1099.

Alvarez, T., Sensini, L., \& Vazquez, M. (2021). Working Capital Management and Profitability: Evidence from an Emergent Economy. International Journal of Advances in Management and Economics, 11(1), 32-39.

Amendola, A., Restaino, M., \& Sensini, L. (2011). Competing risks analysis of the determinants of business exit. Isforges.

Amendola, A., Candila, V., Sensini, L., \& Storti, G. (2020). Corporate Governance, Investment, Profitability and Insolvency Risk: Evidence from Italy. Advances in Management and Applied Economics, 10(4), 185-202.

Arcos, M., \& Benavides, J. (2006). Efecto del ciclo de efectivo sobre la rentabilidad de las firmas Colombianas. Borradores de Economía y Finanzas, 9, 19.

Arellano, M., \& Bond, S. (1991). Some tests of specification for panel data: Monte Carlo evidence and an application to employment equations. Review of Economic Studies, 58(2), 277-297.

Azam, M., \& Haider, S. I. (2011). Impact of Working Capital Management on Firms' Performance: Evidence from Non-Financial Institutions of KSE-30 Index. Interdisciplinary Journal of Contemporary Research in Business, 3(5), 481-492.

Baños-Caballero, S, Garcìa-Teruel, P. J., \& Martınez-Solano, P. (2012). How does working capital management affect the profitability of Spanish SMEs? Small Business Economics, (39), 517-529.

Baños-Caballero, S., García-Teruel, P. J., \& Martínez-Solano, P. (2014). Working capital management, corporate performance, and financial constraints. Journal of Business Research, 67(3), 332-338.

Blinder, A. S., \& Maccini, L. J. (1991). The resurgence of inventory research: what have we learned? Journal of Economic Surveys, 5(4), 291-328.

Boisjolya, R. P., Conine Jr, T. E., \& McDonald IV, M. B. (2020). Working capital management: Financial and valuation impacts. Journal of Business Research, (108), 1-8.

Campos, A., Chen, J., Ferri, G., Parisi, M., Sanchez, J. A., \& Sensini, L. (2014). Business risk prediction models: 
an empirical analysis. International Conference on Accounting and Management Research, 426-445.

Campos, A., Sanchez, J. A., \& Sensini, L. (2015). Efficiency ratio and firm performance: evidence from Italy. IFBE, Dubai.

Chaddad, F. R., \& Mondelli, M. P. (2013). Sources of firm performance differences in the US food economy. Journal of Agricultural Economics, 64(2), 382-404.

Chalmers, D. K., Mannetta, E. W., \& Sensini, L. (2020). R \& D and Internationalization: Effect on the Performance of SMEs. International Journal of Advances in Management and Economics, 9(3), 39-48.

Chalmers, D. K., Mannetta, E. W., \& Zhang, W. (2014). Impact of Working Capital Management Policies on Corporate Performance. ICEFR.

Chalmers, D. K., Sensini, L., \& Shan, A. (2020). Working Capital Management (WCM) and Performance of SMEs: Evidence from India. International Journal of Business and Social Science, 11(7), 57-63, https://doi.org/10.30845/ijbss.v11n7p7

Chen, J., \& Sensini, L. (2014). Net working capital, Cash flow and Performance of SMEs: an exploratory study. Small and Medium Size Enterprises: Governance, Management and Performance (pp. 296-315). Malta Univ. Press.

Chen, J., Hughes, C., \& Sensini, L. (2014). Credit risk measurement of SMEs, International Conference on Economics, Finance and Risk (pp. 139-163).

Das, A., Handfield, R. B., Calantone, R. J., \& Ghosh, S. (2000). A contingent view of quality management-the impact of international competition on quality. Decision Science, 31(3), 649-690.

Deloof, M. (2003). Does working capital management affect profitability of Belgian firms? Journal of Business Finance \& Accounting, 30(4), 573-587.

Diaz, E., \& Sensini, L. (2020). Quality Management Practices, Innovation and Profitability of SMEs: Evidence from Argentina. International Business Management, 14(9), 328-336.

Diaz, E., \& Vazquez, M. (2019). Relationship between WCM and Profitability: first empirical evidence from an emergent economy. DIAF.

Ek, R., \& Guerin, S. (2011). Is there a right level of working capital? Journal of Corporate Treasury Management, $4(2), 137-149$.

Emery, G. W. (1987). An optimal financial response to variable demand. Journal of Financial and Quantitative Analysis, 22(2), 209-225.

Enow, S. T., \& Brijlal, P. (2014). The effect of working capital management on profitability: The case of small, medium and micro enterprises, South Africa. The Journal of Accounting and Management, 4(2), 7-15.

Falope, O. L., \& Ajilore, O. T. (2009). Working Capital Management and Corporate Profitability: Evidence from Panel Data Analysis of Selected Quoted Companies in Nigeria. Research Journal of Business Management, (3), 73-84.

Fazzari, S. M., \& Petersen, B. (1993). Working capital and fixed investment: new evidence on financing constraints. The Rand Journal of Economics, 24(3), 328-342.

Filbeck, G., \& Krueger, T. (2005). Industry Related Differences in Working Capital Management. Journal of Business, 20(2), 11-18.

Gachira, W., Chiwanzwa, W., Nkomo, D. J., \& Chikore, R. (2014). Working capital management and the profitability of nonfinancial firms listed on the Zimbabwe Stock Exchange. European Journal of Business and Economics, 9(2), 12-15, https://doi.org/10.12955/ejbe.v9i2.517

Garcia-Teruel, P. J., \& Martinez-Solano, P. (2007). Effects of Working Capital Management on SME Performance. International Journal of Managerial Finance, 3(2), 164-177.

Gentry, J. A., Vaidyanathan, R., \& Lee, H. W. (1990). A weighted cash conversion cycle. Financial Management, 19(1), 90-99.

Gill, A., Biger, N., \& Mathur, N. (2010). The Relationship Between Working Capital Management and Profitability: Evidence from the United States. Business and Economics Journal, 10, 1-9.

Gitman, L. J. (1974). Corporate liquidity requirements: a simplified approach. The Financial Review, 9, 79-88.

Gul, S., Khan, M. B., Raheman, S., Khan, M. T., Khan, M., \& Khan, W. (2013), Working capital management and 
performance of SME sector. European Journal of Business and Management, 5(1), 60-68.

Hausman, J. (1978). Specification tests in econometrics. Econometrica, 46(6), 1251-1271.

Hirsch, S., Lanter, D., \& Finger, R. (2020). Profitability and profit persistence in EU food retailing: Differences between top competitors and fringe firms. Agribusiness: An International Journal, 121, 1-29.

Hossain, M., \& Kauranen, I. (2016). Open innovation in SMEs: a systematic literature review. Journal of Strategy Management, 9(1), 58-73.

Howorth, C., \& Westhead, P. (2003). The focus of working capital management in UK small firms. Management Accounting Research, 14(2), 94-111.

Iqbal, A., \& Zhuquan, W. (2015) Working Capital Management and Profitability Evidence from Firms Listed on Karachi Stock Exchange. International Journal of Business and Management, 10(2), 231-235. https://doi.org/10.5539/ijbm.v10n2p231

Javid, S., \& Dalian, P. R. (2014). Effect of working capital management on SMEs' performance in Pakistan. European Journal of Business and Management, 6(12), 206-220.

Jose, M. L., Lancaster, C., \& Stevens, J. L. (1996). Corporate return and cash conversion cycles. Journal of Economics and Finance, 20, 33-46.

Karaduman, H. A., Akbas, H. E., Ozsozgun, A., \& Durer, S. (2010). Effects of working capital management on profitability: the case of selected companies in the Istanbul Stock Exchange. International Journal of Economics and Finance Studies, 2, 47-54.

Khoury, N. T., Smith, K. V., \& MacKay, P. I. (1999). Comparing working capital management practices in Canada, the United States and Australia: a note. Canadian Journal of Administrative Sciences, 16(1), 53-57.

Kieschnick, R., Laplante, M., \& Moussawi, R. (2013). Working capital management and shareholders' wealth. Review of Finance, 17(5), 1827-1852.

Kim, Y. H., \& Chung, K. H. (1990). An integrated evaluation of investment in inventory and credit: a cash flow approach. Journal of Business Finance and Accounting, 17(3), 381-389.

Kouvelis, P., \& Zhao, W. (2012). Financing the newsvendor: Supplier vs. bank, and the structure of optimal trade credit contracts. Operations Research, 60(3), 566-580.

Lazaridis, I., \& Tryfonidis, D. (2006). Relationship between working capital management and profitability of listed companies in the Athens stock exchange. Journal of Financial Management and Analysis, 19(1), 26-35.

Lee, H., Kelley, D., Lee, J., \& Lee, S. (2012). SME Survival: The Impact of Internationalization, Technology Resources, and Alliances. Journal of Small Business Management, 50(1), 1-19.

Ling, Y, Simsek, Z., Lubatkin, M. H., \& Veiga, J. F. (2008). Transformational leadership's role in promoting corporate entrepreneurship: Examining the ceo-tmt interface. Academy of Management Journal, 51(3), 557576.

López-Pérez, A., Fernández-López, S., Rodeiro-Pazos, D., \& Li-Bonilla, F. (2018). Análisis en la Relación entre el Fondo de Maniobra y la Rentabilidad: Caso del Sector Oleícola Español. Revista Nacional de Administración, 9(1), 7-25.

Mandujano-Herrera, R., \& Navarro-Orihuela, J. (2015). Factores determinantes del capital de trabajo en empresas manufactureras peruanas y chilenas listadas en el mercado integrado latinoamericano. Working paper de la Universidad del Pacifico.

Mannetta, E. W., Jordan, J. K., \& Zhang, W. (2014). Working capital management and performance: an empirical study. ACRMC.

Marobhe, M. I. (2014). An Empirical Analysis of the Relationship Between Working Capital Management and Profitability: Panel Evidence from Listed Manufacturing Companies in East Africa. European Journal of Business and Management, 6(7), 212-219.

Mathuva, D. M. (2010). The Influence of Working Capital Management Components on Corporate Profitability: A Survey on Kenyan Listed Firms. Research Journal of Business Management, 4(1), 1-11.

McCann, P., \& Ortega-Argilés, R. (2016). Smart specialisation, entrepreneurship and SMEs: issues and challenges for a results-oriented EU regional policy. Small Business Economics, 46(4), 537-552.

Nobanee, H. (2009). Working capital management and firm's profitability: An optimal cash conversion cycle. 
SSRN Electronic Journal. https://doi.org/10.2139/ssrn.1471230

Padachi, K. (2006). Trends in working capital management and its impact on the firm's performance. Analysis of Mauritian small manufacturing firm's. International Review of Business Research Papers, 2(2), 45-58.

Parisi, M., Sanchez, J. A., Sensini, L., \& Vicente, L. (2014). Valuing Private Companies: A Data Envelopment Analysis Approach. Academic Conference on Risk Management and Complexity, 426-439.

Peel, M. J., Wilson, N., \& Howorth, C. A. (2000). Late payment and credit management in the small firm sector: some empirical evidence. International Small Business Journal, 18(2), 17-37.

Prasad, P., Narayanasamy, S., Paul, S., Chattopadhyay, S., \& Saravanan, P. (2019). Review of literature on working capital management and future research agenda. Journal of Economic Surveys, 33(3), 827-861.

Raheman, A., \& Nasr, M. (2007). Working Capital Management and Profitability - Case of Pakistani Firms. International Review of Business Research Papers, 3(1), 279-300.

Sensini, L. (2015). Selection of determinants in Corporate Financial Distress. European Journal of Business and Management, 7(2), 73-82.

Sensini, L. (2020). Working capital management and performance: evidence from Italian SME's. International Journal of Business Management and Economic Research (IJBMER), 11(2), 1749-1755.

Shin, H. H., \& Soenen, L. (1998). Efficiency of working capital and corporate profitability. Financial Practice Education, 8(2), 37-45.

Smith, J. K. (1987). Trade credit and informational asymmetry. Journal of Finance, 42(4), 863-872.

Smith, K. (1980). Profitability versus liquidity tradeoffs in working capital management. In K. V. Smith (Ed.), Readings on the management of working capital (pp. 549-562). St Paul, MN: West Publishing Company.

Stephen, M., \& Elvis, K. (2011). Influence of Working Capital Management on Firms Performance: A Case of SMEs in Kenya. International Business Management, 5(5), 279-286.

Ukaegbu, B. (2014). The significance of working capital management in determining firm profitability: Evidence from developing economies in Africa. Research in International Business and Finance, 31, 1-16.

Vahid, T. K., Elham, G., Mohsen, A. K., \& Mohammadreza, E. (2012). Working capital management and corporate performance: Evidence from Iranian companies. Procedia - Social and Behavioral Sciences, 62, 1313-1318.

Vishnani, S., \& Shah, B. K. (2007). Impact of working capital management policies on corporate performance: An empirical study. Global Business Review, 8(2), 267-281.

Wang, Y. J. (2002). Liquidity management, operating performance, and corporate value: evidence from Japan and Taiwan. Journal of Multinational Financial Management, 12(2), 159-169.

Zayanderoody, M. (2011). A Comparative Study of the Relationship Between Working Capital Management and Profitability of Listed Companies in Tehran Stock Exchange. The Business Review, 17(2), 243-247.

\section{Copyrights}

Copyright for this article is retained by the author(s), with first publication rights granted to the journal.

This is an open-access article distributed under the terms and conditions of the Creative Commons Attribution license (http://creativecommons.org/licenses/by/4.0/). 